\title{
e-Phaïstos
}

e-Phaïstos

Revue d'histoire des techniques / Journal of the history

of technology

V-2 | 2016

Histoire des techniques en Afrique de l'Ouest

\section{The History of Russian Railway Museums}

Histoire des musées de chemins de fer en Russie

\section{Anastasiia Glushko}

\section{OpenEdition}

\section{Journals}

Electronic version

URL: http://journals.openedition.org/ephaistos/6089

DOI: 10.4000/ephaistos.6089

ISSN: 2552-0741

Publisher

IHMC - Institut d'histoire moderne et contemporaine (UMR 8066)

\section{Printed version}

Date of publication: 15 June 2016

Number of pages: $122-127$

ISSN: 2262-7340

Electronic reference

Anastasiia Glushko, «The History of Russian Railway Museums », e-Phaïstos [Online], V-2 | 2016,

Online since 15 March 2020, connection on 17 June 2020. URL : http://journals.openedition.org/

ephaistos/6089 ; DOI : https://doi.org/10.4000/ephaistos.6089 


\title{
The History of Russian Railway Museums
}

\author{
Anastasiia Glushko \\ Doctorante FGBOU VPO \\ Université d'Etat des Transports de \\ Rostov-sur-le-Don
}

Railways in Russia are the most sought-after, veritably public means of transportation. However, from everything that concerns transit, people somehow know the least about the railways and their daily existence. Everyone can distinguish car brands, however it is rare that passengers can tell, for example, on which train they travel every day to work or to other cities. This is all the more true concerning older trains - steam locomotives, railway station bells, water stations, and semaphores. But the history of railways is an important part of Russian history. Without exaggeration, the railways changed the secular development of life in Russia. They had a tremendous influence on the industrial development of the country, on its culture and on the pace of life.

The importance of railway transport is not only in the movement of passengers and the transportation of goods, but also in the demonstration of the historical periods of development of the country.

In Russia, there are hundreds of railway museums and expositions, mostly at train stations, depots and locomotive monuments. Relatively large outdoor collections belonging to the Ministry of Railways were created in Moscow, St. Petersburg, Nizhny Novgorod, Rostov-on-Don, Chelyabinsk, Yekaterinburg, Novosibirsk, Kaliningrad, Kemerovo, and Kirov. Of the greatest interest to fans of large railway exhibitions are the collections of real rolling stock as well as technical devices connected to railways. Visiting such exhibitions gives the opportunity to make a journey through time, seeing the railway equipment of different eras.

Two of the largest and most interesting rail museums in Russia are located in Saint Petersburg and Rostov-on-Don. The largest was opened in 1987 at Shushary station, near Leningrad, and is now situated on the platforms of the former Warsaw station. Tourist and holiday trips to visit the restored trains are regularly organized in Russia. Historical visits solely on the steam haulage route between Moscow and Vladivostok has even made it into the Guinness Book of Records.

During the period of the Soviet Union, railway enthusiasts could only dream of a museum about locomotives in their country. It seemed as though it were impossible to overcome the bureaucratic wall 1 . There are some cases wherein the old railwaymen, who understood the value of the extant collections of steam locomotives, took care of them of their own initiative, considering them as a continuation of the memory of their profession. The depot chiefs, however, ordered that everything be sold for scrap. In many depots, the workers put the vintage locomotives on pedestals as monuments of the combat or glory of labor. But the monuments weren't museums, but rather something local, and they couldn't solve the problem of perpetuating the memory of the railway at the level which it deserves. 
In Russia, the history of railway museums begins in 1813 , when in Saint Petersburg, at the Institute of Railway Engineers, a museum, now called the "Central Museum of Railway Transport of Russia", was created. Initially, it was intended for educational purposes. In 1823 the museum, together with the institute, was transferred to a new building, and in the new constitution of the Institute it was reported that the museum should be used not only by teachers and students, but also by all railway departments. Since 1862, on certain days of the week, it began to be open to the public at large. The collections of the museums were continuously updated with new items. In the second half of the 19th century, most of the exhibits were received in the form of gifts from various institutions, companies and citizens. The museum was given personal things of former railway ministers. Professor Y. N. Gordeenko, who was the curator of the museum for twenty years, donated several models from his own scientific research to the museum.

In 1896 it had been 100 years since the birthday of Emperor Nicholas I, who played a major role in the creation of the first railways in Russia. Minister of Railways M. I. Khilkov offered to create a museum for different models, constructions, shells, and machines in St. Petersburg in one of the administration buildings and gave it the name of the founder of the railways in Russia. This offer was approved by Nicholas II in 1896. The space within the dedicated building, however, was not enough for a museum bearing the name of the emperor. Consequently, the State Council decided to erect a new building on the land which belonged to the Department of Railways with the main façade on Sadovaya Street. It was also decided to send exhibits of Russian rail and water departments to the museum in the name of Nicholas I from the world technical exhibition of Paris in 1900. As was mentioned in the tenth issue of the "Journal of Communications" of 1901, among the exhibits from the exhibition "the following items deserve special attention: Peter's I model "Plaisir yacht", the panorama of the Siberian railway (Dr. Piasecki's), models of the icebreaker "Baikal", models of bridges over the Volkhov and Yenisei Rivers, and a model of a new locomotive assembly workshop of the Nikolaev railway."

In 1901, in the presence of the minister of railways, construction of the museum was begun. The consecration and opening of the museum of the Department of Transport named after the emperor Nicholas were held in 1902.

In 1903, Emperor Nicholas II visited the museum. After the visit, he donated some of Nicholas I's personal belongings from the imperial palaces to the museum, including a number of models, such as that of the steam locomotive Rostov-Vladikavkaz railway with a nominal sign "S. Kerbedz. 1894".

In 1904 a two-storey pavilion was built on the south side of the museum. In 1905, Peter's I small boat, Alexander II's autoboat, two banners from the Ladoga battalion of the Department of Transport, which had previously been stored in Schlusselburg, were put into the pavilion.

By 1909, a project to build additions to the museum was developed. In 1910 the left side was built. In the same year, in the centenary of the founding of the Institute of Railway Engineers, the main part of the institute museum was moved from the building on Moscow Avenue to a new building. Later, the institute museum and railway museum werre combined into one.

During the first years of Soviet power, because of the civil war and the ensuing post-war devastation, funds for the museum weren't given. As a result, the building was not heated and the work in the museum was not organized. The museum staff consisted of a curator and one watchman. However, thanks to the efforts of professors and students at the Leningrad Institute of Railway Engineers, it was able to preserve its unique collection.

In 1924, the museum was opened to visitors. During the opening of the museum the exhibits 
were located in by order of historical development in five departments: general, bridge, rail, water, and architecture.

Higher education was reorganized between 1930 and 1931. From the Leningrad Institute of Railway Engineers the following faculties were separated: the water faculty, the air faculty, the road faculty, and the military faculty, all of which became independent universities. After the separation of the faculties, the institute started to work primarily within the sphere of railway transport training. For this reason it was renamed the Leningrad Institute of Railway Engineers in 1930.

In 1933, the People's Commissariat for Lines of Communication accepted the museum under its direct subordination. The museum staff did a lot of work on its restoration and in 1934 the museum was opened to the public. In the holdings of the museum there were 11,843 subjects, including 490 models and layouts. For the first time the museum began to work outside of its own building. Pavilion branches were created in the two largest parks of the city and traveling exhibitions were organized. In 1938, the museum became part of the Leningrad Institute of Railway Engineers.

After the beginning of the World War II, the most valuable collections of the museum were evacuated to Novosibirsk and the museum was closed. In an effort to maintain order and protect the museum, four employees, headed by the deputy director of the museum, stayed. Between 1941 and 1942 the territory of the Leningrad Institute of Railway Engineers was attacked during a bombing. Because of the explosion of shells, glass in the building was destroyed. As a result, the museum staff boarded up the windows. Due to direct hits by two shells, the central hall's ceiling was destroyed.

After the end of the Siege of Leningrad in March of 1944, the museum collections were brought back from Novosibirsk. Staff members then began the work of repairing the basic models as well as the restoration of exhibitions. The museum was opened to the public on May 18, 1948. In the summer of
1948 the first post-war exhibition was organized in honor of the holiday for railwaymen in the Central Park of Culture and Rest in Leningrad. In 1948 the first post-war inventory was conducted at the museum. There were 2,001 museum objects in total and 760 items in the inventory.

In 1987 an important event in the history of the museum occurred when it became the Central Museum of Railway Transport of the Ministry of Railways. This change of status allowed for the museum to solve any problems regarding the acquisition of funds, increasing research, and expanding exhibitions.

The museum's collection currently contains more than sixty thousand items. Collections of the history of rolling stock: albums, drawings, photographs, and books; more than 300 models of locomotives (steam, diesel, and electric locomotives) as well as coaches and about 50 fullsized locomotives.

Collections in the museum also include visual documents on the history of railway construction in Russia, and the formation and development of national railway science and technology. The museum staff is constantly organizing the research work in its archives and libraries. The museums exhibits, used by researchers and writers, are also used for the preparation of films and videos and the organizing of new museums. Additionally, they aid in excursion and vocational guidance work as well as extracurricular classes for students. Exhibition work allows visitors to become more acquainted with the exhibits. The museum holds around twelve to fifteen exhibitions throughout the year.

Currently the Federal State Institution of Culture "Central Museum of Railway Transport of the Russian Federation" is a scientific and methodological center for the museums of the railway network of JSC "Russian Railways". Representatives of 250 railway museums apply to the Central Museum of Railway Transport of the Russian Federation with different questions, with many of them taking part in study placements, 
systematically conducted seminars, as well as obtaining materials and necessary consultations.

The Central Railway Museum is one of the oldest technical museums in the world. The layout of the museum's exhibitions, built in chronological order, are situated in $\mathbf{1 1}$ halls. By passing through them visitors get a complete presentation about the development of the Russian railway industry, from the birth of the railways to the present day. The richest photo collection in the museum shows the methods used in the construction of railways in Russia and the formation and development of railway technology.

The museum has extensive international connections. It is a member of the Union of Russian Museums, the International Council of Museums (ICOM), the Association of Science and Technology Museums in the Russian Committee of the International Council of Museums, the European Association of Museums, and (FEDECRAIL) the European Federation of Museum and Tourist Railways.

In the south of the vast expanses that make up Russia, in the city of Rostov-on-Don, there is a large museum which serves as an introduction to the nation's railway history .

The Rostov Museum of Railway Transport of the Russian Federation, devoted to railways and rolling stock, is one of the first national museums in the south of Russia. It was established in 1960 in the Palace of Culture of Railwaymen in Rostov-onDon $^{2}$. The initiative for this museum came from veterans of railway transport. They were dedicated to the railway, giving it fifty or more years of their working lives. The museum worked on a voluntary basis, its council consisting of thirty people. Although they've all since died, their memories live on through the preservation of the history of their native railway. The work of their lives has now existed for more than forty-three years. On the North Caucasian Railways today, there are 14 museum enterprises, including the Krasnodar and Mineralnye Vody branches.
Today the exhibition space of the railway museum is 560 square meters. From the very first days of its existence it has been a popular attraction of Rostov-on-Don, as the history of the railway is an integral part of the history of the city and the entire North Caucasus region.

More than ten thousand people are employed by all forms of museum work each year. The work isn't only excursions but also traveling exhibitions, retro tours, dramatized scenes from the history of railroads, consultations, lessons with young local historians, meetings with veterans of war and labor as well as leaders of industry.

Rostov Railway Museum makes a significant contribution to the study of the history of railway transport. Because its employees were able to increase the funds to the museum, today there are more than eight thousand items: photographs, documents and books from the 19th and 20th centuries, awards, badges, models and patterns, means of signaling and communication, railmen's personal belongings, travel tools, amongst others. The main keeper of the museum funds, I.A. Kovaleva, liaises with the veterans, and it is thanks to her efforts that many people transfer relics dear to their hearts to the museum.

On August 1, 2003, on the eve of the Day of Railwaymen, a major event was held: the opening of the Museum of Railways in Gnilovskaya Station, in Rostov-on-Don, which became a branch of the Rostov Museum of Railway Transport of the Russian Federation.

The idea of creating the museum originated in 1991. Enthusiasts organized in the same year, they included the All-Union Society of Railways, students from Rostov State Transport University, and railway workers (veterans V. Burakov V. Vlasenko, Volkov, S. Danilov, M. Dudnik, H . Storozhuk, M. Maslov, D. Yevtushenko, A. Shulga), who set a challenge to make a collection of old rolling stock. The initiative was supported by the Rostov Museum of Railway Transport. 
The total length of the exposure pathways of the museum is 1,900 meters. Today, forty-five exhibits are located there: steam locomotives, diesel locomotives, electric locomotives, electrical trains, passenger and freight cars, a semaphore, traffic lights and a hydrostation. It is necessary to restore another twenty items from the collection of rolling stock, including the oldest surviving Russian railroad cars, produced by the English factory "Gloucester" in 1869.

The museum is the second in Russia in terms of the uniqueness of its collection as well as the number of existing exhibits.

Railway transport was created for traveling, so railway museum employees regularly organize tourist visits and holiday trips on restored transport.

During the celebration of the 150th anniversary of Russian railways on November 15, 1987 in Leningrad, there was an event perceived as an unprecedented miracle. Passengers, along with a delegation of guests of the festival and headed by the Minister of Railways, had a trip on a steam locomotive to Pavlovsk on the former railroad Tsarskoye Selo. And it wasn't just a steam locomotive, but PZ6 - the last domestic passenger steam locomotive. Thousands of people stopped near the tracks of the oldest railroad in Russia and admired the train's voyage.

On the same day, on the observation platform of Vitebsk Station, was the only surviving Soviet workable hot steam locomotive, Ov-324. People could go up to it to touch it and thus see that it was hot and operational. A live steam locomotive is not just a visual spectacle; it is the smell of burning lubricants, jets of steam, and the heat of the furnace: it is power. It was on that day that the revival of Russia's existing locomotives began.

Currently, the steam locomotive TCH-7 makes regular tourist trips with the "bourgeois" trains from St. Petersburg to Pavlovsk and participates in commercial retro trips for foreigners, bringing the company additional income. The steam locomotives are used in filming. The JSC Company "Russian Railways" is the only one in the transport sector which pays so much attention to preserving the history of its industry and holds unique retro trips for Russian citizens. Every year on May 9 in Moscow, St. Petersburg, Novosibirsk, Rostov-onDon, Chita, and Chelyabinsk the retro train "veterans" set forth with steam power.

Since March 2005 in Rostov-on-Don, for the first time in Russia, regular retro trips using steam power with a tour service, along with visits to the museum of natural samples located in Gnilovskaya Station, have been organized by company "Delta Copy", in conjunction with the North Caucasian road for Russian citizens, primarily for schoolchildren. It is also a landmark moment and thanks to Rostovites that steam train retro trips have, for the first time in the history of Russian railroads, become everyday occurrences.

In order to have the possibility for visitors to Russian museums to admire railway exhibits from various periods, a long-term effort by people who have dedicated their lives to studying the history of railways was necessary. Today, the scientific work on the studying of railway transport history continues; various scientific associations are being created, different forums of exchange of experience and improving the railway transport industry are being organized, which have the inevitable result of better and better museums.

1 VULFOV A.B., Everyday life of Russian railways, Moscow, Molodaya Gvardiya, 2007.

2 SIDORENKO V.T., NEKRASOVA Y.P., BUTKO V.A., North Caucasian railway in three centuries: dedicated to the 140th anniversary of the North-Caucasian railways, Rostov-on-Don, 2004. 


\section{Bibliographie :}

SIDORENKO V.T., Selected events from the history of the North-Caucasian railways, Rostov-onDon, "New Book", 2002.

SIDORENKO V.T., NEKRASOVA Y.P., BUTKO V.A., North Caucasian railway in three centuries: dedicated to the 140th anniversary of the NorthCaucasian railways, Rostov-on-Don, 2004.

VULFOY A.B., Everyday life of Russian railways, Moscow, Molodaya Gvardiya, 2007.

\section{Webographie :}

Central Museum of Railways of Russian Federation: www.cmzt.narod.ru

The Federal Agency of Railway Transport (Roszheldor): www.roszeldor.ru 